\title{
A Hydrogen Peroxide Biosensor from Horseradish peroxidase Immobilization onto Acrylic Microspheres
}

(Biosensor Hidrogen Peroksida Berasaskan Pemegunan Peroksidase Lobak Putih pada Mikrosfera Akrilik)

\author{
EdA YuHANA ARIFFIn, NiK NuRHANAN NIK MANSOR, EKA SAFITRI, LEE YoOK HENG \\ \& NURUL IZZATY HASSAN*
}

\begin{abstract}
The sensitive and rapid detection of hydrogen peroxide is very important in the areas of clinical and environmental analyses. A sensitive and selective Horseradish peroxidase (HRP)-hydrogen peroxide $\left(\mathrm{H}_{2} \mathrm{O}_{2}\right)$ biosensor was developed based on acrylic microspheres. Hydrophobic poly(n-butyl acrylate-N-acryloxysuccinimide) [poly(nBA-NAS)] microspheres were synthesized using photopolymerization in an emulsion to form an enzyme immobilization matrix. The HRP enzyme was covalently immobilized onto the acrylic microspheres via the succinimide functionality. Field emission scanning electron microscope (FESEM) has been utilized to characterize the screen-printed carbon paste electrode (SPE) constructed from enzyme conjugated acrylic microspheres and gold nanoparticles (AuNPs) composite (HRP/nBA-NAS/AuNPS/SPE). Differential pulse voltammetry was used to assess the biosensor performance. The linear response range of the hydrogen peroxide biosensor obtained was from $1.0 \times 10^{-2}$ to $1.0 \times 10^{-10} \mathrm{M}\left(R^{2}=0.99\right)$ with the limit of detection (LOD) approximately at $1.0 \times 10^{-10} \mathrm{M}$. This is an improvement over many hydrogen peroxide biosensors reported so far. Such improvement may be attributed to the large surface area provided by the acrylic microspheres as a matrix for immobilization of the HRP enzyme.
\end{abstract}

Keywords: Acrylic microsphere; biosensor; Horseradish peroxidase; hydrogen peroxide

\section{ABSTRAK}

Pengesanan hidrogen peroksida yang sensitif dan cepat adalah sangat penting dalam bidang analisis persekitaran dan klinikal. Biosensor hidrogen peroksida $\left(\mathrm{H}_{2} \mathrm{O}_{2}\right)$-peroksidase lobak putih (HRP) yang sensitif dan memilih telah dibangunkan berasaskan mikrosfera akrilik. Mikrosfera hidrofobik poli(n-butil akrilat-N-akriloksuksinimida)[poli(nBA-NAS)] disintesis dengan menggunakan proses fotopempolimeran dalam bentuk emulsi dan ia bertindak sebagai matriks pemegun enzim. Enzim HRP dipegunkan secara kovalen pada mikrosfera akrilik melalui pengfungsian suksinimida. Mikroskop elektron imbasan pancaran medan (FESEM) telah digunakan bagi mencirikan elektrod karbon permukaan bercetak (SPE) yang dibina daripada komposit mikrosfera akrilik berkonjugat enzim dan nanosfera emas (AuNPS) (HRP/nBA-NAS/AuNPS/SPE). Voltametri denyutan pembezaan digunakan untuk penilaian prestasi biosensor. Julat keupayaan linear bagi biosensor hidrogen peroksida diperoleh daripada $1.0 \times 10^{-2}$ hingga $1.0 \times 10^{-10} \mathrm{M}\left(R^{2}=0.99\right)$ dengan had pengesanan (LOD) ditemui pada $1 \times 10^{-10} \mathrm{M}$. Ini merupakan penambahbaikan berbanding biosensor hidrogen peroksida yang telah terlebih dahulu dilaporkan. Penambahbaikan ini mungkin ditentukan oleh luas permukaan yang besar yang disediakan oleh mikrosfera akrilik sebagai tapak pemegunan enzim HRP.

Kata kunci: Biosensor; hidrogen peroksida; mikrosfera akrilik; peroksidase lobak putih

\section{INTRODUCTION}

For the past 50 years, there has been an increase in the development of amperometric biosensors for hydrogen peroxide detection especially in clinical chemistry and medical purposes (Hirst el al. 2013). The sensitive and rapid detection of hydrogen peroxide is very important in chemical, biological, clinical, environment and many other fields (Ciszewski \& Gorski 1995). Many techniques such as titrimetry, spectrometry, chemiluminescence and electrochemistry have been used for the determination of hydrogen peroxide. Among these techniques, the electrochemical biosensor method based on electron transfer between an electrode and immobilized HRP has received the most attention because of its simplicity, high sensitivity and low-cost enzyme sensors (Fang et al. 2011; Wang \& Wang 2004).

Hydrogen peroxidase (HRP) is the most commonly used enzymes for the development of hydrogen peroxide biosensor. HRP has been one of the most widely studied enzymes in the development of amperometric biosensors because of the availability in high purity, low cost and high stability (Radi et al. 2008). The enzyme contains heme as a prosthetic group, which is also the protein active site with the resting state of the heme-iron: Fe(III), and it can catalyze the $\mathrm{H}_{2} \mathrm{O}_{2}$-dependent one-electron oxidation of various substrate (Wang \& Wang 2004; Zhang et al. 
2000). Hydrogen peroxide biosensors commonly involved an immobilization of hydrogen peroxidase enzyme onto suitable matrices. In electrochemical applications, oxidases are the most widely used enzymes family (Ricci et al. 2003). An enzyme electrode for the determination of blood glucose was explained based on amperometric observation of the released hydrogen peroxide (Guilbault \& Lubrano 1973).

In the development of amperometric enzyme electrodes, they are vast difference in the design or material of the electrodes, immobilization matrices composition or immobilization approaches. The immobilization method and matrix used for enzyme immobilization are important in designing a hydrogen peroxide biosensor. There were various methods and type of matrices have been reported including adsorption, cross-linking (Lin et al. 2000; Xu et al. 1998), layer-by-layer assembly (Chen et al. 2006; Zhang et al. 2001), covalent binding (Senel et al. 2010), sol-gel entrapment (Lei et al. 2004), nano or even micro materials (Yu et al. 2006), film (Cao et al. 2008) However, many of them produced weak molecular bonds between enzymes and immobilization matrix (Garjonyte et al. 2001), which affecting the reduction of shelf life and stability of biosensor. Clark and Lynos proposed the firstgeneration devices that used the production and detection of hydrogen peroxide (Wang 2001). A hydrogen peroxide biosensor used new methylene blue $\mathrm{N}$ incorporated in a montmorillolite colloidal particles- modified horseradish peroxidase immobilization matrix as electron shuttle (Lei et al. 1996). The cyclic voltammetry and amperometric measurement displayed good stability, whereby the biosensor responded rapidly to $\mathrm{H}_{2} \mathrm{O}_{2}$ in the linear range from $5.0 \mu \mathrm{M}$ to $2.2 \mu \mathrm{M}$ with the detection limit of $6.0 \times$ $10^{-7} \mathrm{M}$. Anthraquinone was later introduced as sensing material for redox mediation of HRP on a glassy carbon electrode substrate for hydrogen peroxide sensing with detection limit of $40 \mathrm{nM}$ (Duo et al. 2009). Ansari research group found that fabrication of $\mathrm{HRP} / \mathrm{NanoCeO}_{2} / \mathrm{ITO}$ gives a linear range of $1.0-170 \mu \mathrm{M}$ and it can be use about 20 times (Ansari et al. 2009).

Subsequently, HRP was immobilized in a nanocomposite films of carbon nanotubes (CNTs)-SBA-15 modified gold electrode. This biosensor showed a linear range from $1 \mu \mathrm{M}$ to $7 \mathrm{mM}$ and detection limit of $0.5 \mu \mathrm{M}$ (Fang et al. 2011). In the same year, Villalonga et al. (2011) developed a wiring HRP on gold nanoparticles-based nanostructured polymeric network for the construction of mediatorless hydrogen peroxide biosensor. The so-called reagentless biosensor for $\mathrm{H}_{2} \mathrm{O}_{2}$ exhibited a linear range from $5 \mu \mathrm{M}$ to $1.1 \mathrm{mM}$ with rapid response within $8 \mathrm{~s}$. In 2015, Zhang et al. deposited gold nanoparticles (AuNPs) onto a three dimensional (3D) porous carbonized chicken eggshell membrane (CESM) to increase the performance of the biosensor. The linear range was found between $0.01-2.7 \mathrm{mM}$ with detection limit of $3 \mu \mathrm{M}$.

A similar detection limit was achieved at $2.6 \mu \mathrm{M}$ with the immobilized HRP on a glassy carbon electrode by poly(glycidyl methacrylate-co-vinylferrocene)
(poly(GMA-co-VFc)) film (Senel et al. 2010) with linearity occurred in the range of 2.0-30.0 mM. Much lower linear range from $2.65 \times 10^{-9}$ to $1.08 \times 10^{-7} \mathrm{M}$ with detection limit of $1.44 \times 10^{-9} \mathrm{M}$ was obtained for hydrogen peroxide detection with immobilized anthraquinone 2-carboxylic acid modified HRP (Shourian \& Ghourchian 2010). It is noteworthy to mention that all these biosensors have short linear range and low sensitivity.

The fabrication of an efficient biosensor relies on the structure and surface morphology of the enzymes supporting materials. The use of large surface area materials such as microparticles or nanoparticles would allow more effective loading of enzymes on the materials and increase the biosensor sensitivity compared with one-dimensional structure membrane (Ulianas et al. 2014). Here, we developed a novel hydrogen peroxide biosensor based on immobilizing HRP onto the acrylic microspheres. Acrylic microspheres were synthesized with the use of n-butyl acrylate (nBA) monomer, sodium dodecyl sulphate (SDS), 1,6-hexanadiol diacrylate (HDDA), N-acryloxysuccinimide (NAS), 2-2-dimethoxy-2-phenylacetophenone (DMPP) and water. The covalent bond was formed between the succinimide group of acrylic microsphere and an amine group of HRP enzyme as in Figure 1. We had investigated the potential of a hydrogen peroxide biosensor constructed by depositing a AuNPs/acrylic microspheres composite on screen-printed carbon paste electrode. The AuNPs were used to enhance the conductivity of the hydrogen peroxide biosensor (Nik Mansor et al. 2018). Hydrogen peroxide were quantified by different pulse voltammetry (DPV) in the presence of potassium ferum (III) cyanide $\left(\mathrm{K}_{3} \mathrm{Fe}(\mathrm{CN})_{6}\right)$ as mediator.

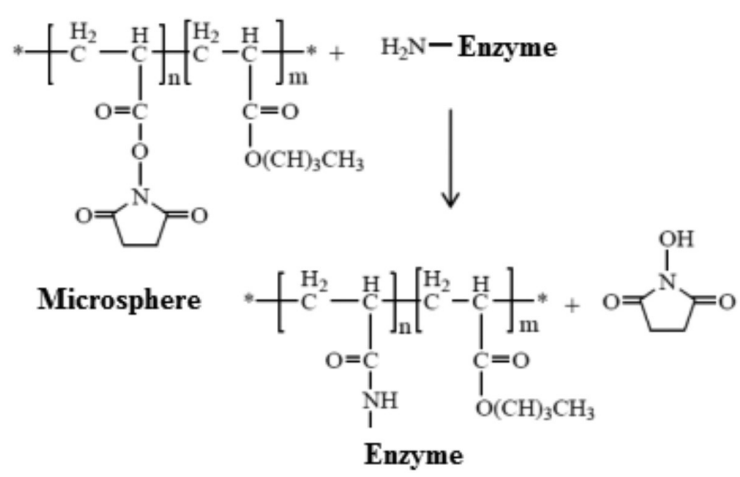

FIGURE 1. Schematic reaction of involving HRP enzyme binding on acrylic microsphere

\section{MATERIALS AND METHODS}

\section{CHEMICAL AND REAGENT}

Chemicals were obtained from commercial suppliers, namely; hydrogen peroxide (Merck), n-butyl acrylate (n-BA) (Merck), 2-2-dimethoxy-2-phenylacetophenone (DMPP) (Fluka), ethanol (EtOH), 1,6-hexanediol diacrylate (HDDA) (Aldrich), Sodium dodecyl sulfate (SDS) (Systerm), 
$\mathrm{N}$-acryloxysuccinimide (NAS) (Acros), 95\% ethanol (Systerm), potassium diphosphate $\left(\mathrm{K}_{2} \mathrm{HPO}_{4}\right)$ (Fluka), potassium phosphate $\left(\mathrm{KH}_{2} \mathrm{PO}_{4}\right)$ (Merck), potassium chloride $(\mathrm{KCl})$ (Systerm) and potassium ferum (III) cyanide $\left(\mathrm{K}_{3} \mathrm{Fe}(\mathrm{CN})_{6}\right)$ (Merck). Peroxidase from horseradish was purchased from Sigma and gold nanoparticles (AuNPs) powder from Aldrich. K-buffer solution (PBS) was prepared by mixing $\mathrm{K}_{2} \mathrm{HPO}_{4}$ and $\mathrm{KH}_{2} \mathrm{PO}_{4}$. Deionized water (18 $\mathrm{M} \Omega \mathrm{cm}$ ) was used to prepare all aqueous phase.

\section{INSTRUMENTATION}

Differential pulse voltammetry (DPV) measures the electrochemical responses using the potentiostat (Autolab model, Metrohm). The electrochemical system consists of three type of electrodes which are carbon screen electrode (SPE) as working electrode, a rod-shaped platinum electrode as counter electrode and $\mathrm{Ag} / \mathrm{AgCl}$ electrode as reference electrode.

\section{SYNTHESIS OF ACRYLIC MICROSPHERE}

Acrylic microspheres were prepared by following the procedure described by Ulianas et al. (2011). Briefly, the microspheres were synthesized by mixing of $7 \mathrm{~mL} \mathrm{nBA}$ monomer, $0.01 \mathrm{~g}$ SDS, $450 \mu \mathrm{L}$ HDDA, $0.1 \mathrm{~g}$ DMPP, $6 \mathrm{mg}$ NAS and $15 \mathrm{~mL} \mathrm{H}_{2} \mathrm{O}$ in a small conical flask. At room temperature, the mixture was sonicated for $10 \mathrm{~min}$. The resulting white emulsion solution was photocured for $600 \mathrm{~s}$ with UV light under continuous nitrogen gas flow. The poly(nBA-NAS) microspheres were collected under centrifugation at $4000 \mathrm{rpm}$ for $30 \mathrm{~min}$ with minimum three times wash using potassium phosphate (K-phosphate) buffer. Subsequently, the collected microspheres were left to dry at ambient temperature.

\section{FABRICATION OF HRP/MSP-NAS/AUNPS/SPE BIOSENSOR}

$16 \mu \mathrm{L}$ of gold nanoparticles (AuNPs) were suspended in ethanol ( $1 \mathrm{mg}$ AuNPs dissolved in $300 \mu \mathrm{L} \mathrm{EtOH}$ ) was deposited onto a SPE and left it to dry at rt. 0.5 mg horseradish peroxide (HRP) was mixed in $100 \mu \mathrm{L}$ K-phosphate buffer solution (0.05 M,pH7). $1 \mathrm{mg}$ acrylic microspheres (MSP-NAS) were mixed in $100 \mu \mathrm{LK}$-phosphate buffer solution (0.01 M, pH7). The acrylic microspheres (MSP-NAS) and HRP were immobilized together for $24 \mathrm{~h}$ and keep refrigerated at $4^{\circ} \mathrm{C}$. Next, the mixture of HRP/ MSP-NAS were centrifuged at $10000 \mathrm{rpm}$ for $8 \mathrm{~min}$ at $4^{\circ} \mathrm{C}$ and washed with K-phosphate buffer solution $(0.01 \mathrm{M}$, $\mathrm{pH} 7$ ) for three times. HRP/MSP-NAS was suspended back in K-phosphate buffer solution before quickly dropped onto the SPE. $8 \mu \mathrm{L}$ of immobilized suspension (HRP/MSPNAS) was dropped onto modified AuNPs/SPE and stored at $4^{\circ} \mathrm{C}$ for drying. The biosensor response was investigated by means of DPV. The stepwise fabrication of the HRP/ MSP-NAS/AuNPs/SPE biosensor is depicted in Figure 2. Potassium ferricyanide, $\mathrm{K}_{2} \mathrm{Fe}(\mathrm{CN})_{6}$ acts as mediator for the determination of hydrogen peroxide.

\section{OPTIMIZATION OF HYDROGEN PEROXIDE BIOSENSOR}

The amounts of AuNP and MSP-NAS deposited on the SPE were optimized by varying the amount of AuNP and MSP-NAS from $0-0.08 \mathrm{mg}$. Similarly, the amounts of HRP were varied between $0.08-0.23 \mathrm{mg}$ while the amount of gold nanoparticles and MSP-NAS were kept constant. The effect of three different buffer type to hydrogen peroxide biosensor was investigated using K-phosphate, Sodiumphosphate (Na-phosphate) and tris- $\mathrm{HCl}$ buffers of 0.01 $\mathrm{M}$ and $\mathrm{pH}$. The effect of buffer $\mathrm{pH}$ was determined with $0.01 \mathrm{M}$ K-phosphate buffer in the $\mathrm{pH}$ range from 5 to 9 . Simultaneously, the effect of buffer concentration was examined with varied concentration of K-phosphate buffer from $0.5 \mathrm{mM}$ to $50 \mathrm{mM}$.

\section{HYDROGEN PEROXIDE BIOSENSOR'S RESPONSE}

The calibration curve of the hydrogen peroxide biosensor was obtained in a series of hydrogen peroxide concentration from $1 \times 10^{-10} \mathrm{M}$ to $1 \times 10^{-2} \mathrm{M}$. The reproducibility of the hydrogen peroxide was subsequently studied utilizing three replicate units of biosensors and tested with $1 \times 10^{-6}$ $\mathrm{M}$ of hydrogen peroxide. In addition, the repeatability of the biosensor was examined by measuring response of one biosensor for 7 times. Lastly, the shelf life of the hydrogen peroxide biosensor was explored by using electrodes stored at $4^{\circ} \mathrm{C}$. These electrodes were tested in triplicates with 1

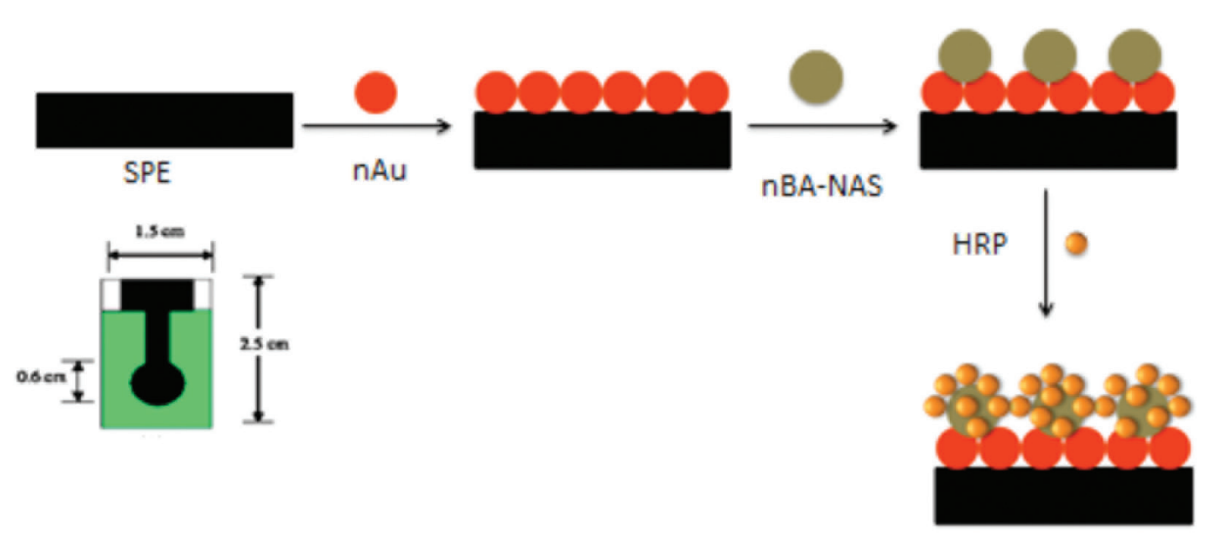

FIGURE 2. The stepwise fabrication of the HRP/MSP-NAS/AuNPs/SPE 
$\times 10^{-5} \mathrm{M}$ of hydrogen peroxide in $0.01 \mathrm{M}$ K-phosphate buffer, $\mathrm{pH} 7$ at fixed intervals for up to a duration of 30 days where a substantial decline in the biosensor response was realized at potential $0.2 \mathrm{~V}$.

\section{RESULTS AND DISCUSSION \\ CHARACTERISATION OF MODIFIED HRP/MSP-NAS/AUNPS/SPE}

Acrylic microspheres were non-conducting materials, and thus the addition of gold nanoparticles could enhance the electron transfer from the mediator $\left(\mathrm{K}_{2} \mathrm{Fe}(\mathrm{CN})_{6}\right)$ to SPE surface (Ulianas et al. 2012). The experiment showed a gradual increase of biosensor response from 0.02 to 0.04 mg AuNPs but a sudden increase with almost two-fold current by $1 \mathrm{mg}$ particle up to $0.05 \mathrm{mg}$ were observed. Following this, a sudden decrease was noticed when nanoparticle was increased up to $0.07 \mathrm{mg}$ (Figure 3(a)). The increase of peak current with increased nanoparticle amount was due to the increase of conduction pathway for electron transfer generated by the AuNPs (Ulianas et.al 2011). The decrease in current above $0.07 \mathrm{mg}$ nanoparticles can be related to the complete coverage of nanoparticles on the SPE surface, hence hampering the electron transfer efficiency at the electrode surface (Ariffin et al. 2018).
Figure 3(b) shows the effect of MSP-NAS amount on the biosensor response. The $\mathrm{H}_{2} \mathrm{O}_{2}$-HRP biosensor response elevated simultaneously with the increase amount of MSP-NAS up to $0.04 \mathrm{mg}$ and later decreased when the amount was further raised. This can be explained mainly by the increment of the surface area for HRP enzymes to be immobilized onto the surface as the concentration of MSP-NAS was increased. The total coverage or saturation will hinder the electron transfer and lower the DPV response (Ariffin et al. 2018; Ulianas et al. 2018). The peak current escalated proportional with the increasing amount of enzymes from 0.08 to $0.19 \mathrm{mg}$. Further increase caused the current to decrease due to the saturation of the MSPNAS with HRP enzymes (Figure 3(c)). Thus, a similar explanation as mentioned above is applicable.

The different types of buffer solution, $\mathrm{pH}$ and buffer concentration were optimized to achieve the optimal condition to enhance the reaction of HRP enzymes and $\mathrm{H}_{2} \mathrm{O}_{2}$. In all three cases, there is an optimum value where the biosensor gave the maximal current response for the highest degree of reaction between HRP enzymes and $\mathrm{H}_{2} \mathrm{O}_{2}$. The $\mathrm{H}_{2} \mathrm{O}_{2}$-HRP biosensor showed the best response in 0.01 M K-phosphate buffer at pH7 (Figure 4(a)) in the way that it provided a suitable environment for enzymes compared with $\mathrm{Na}$-phosphate and tris- $\mathrm{HCl}$ buffer solutions. Thus,

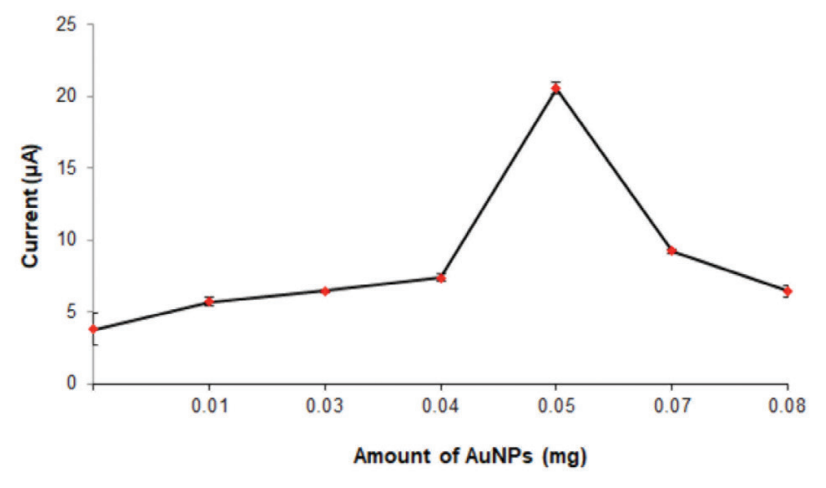

(a)

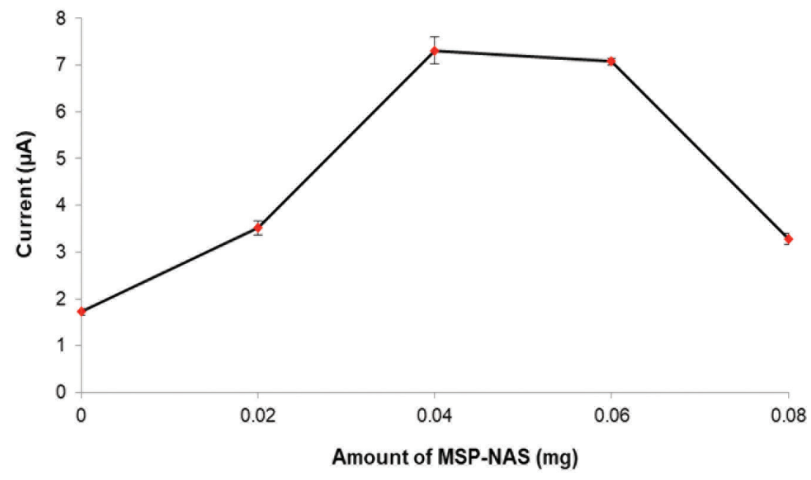

(b)

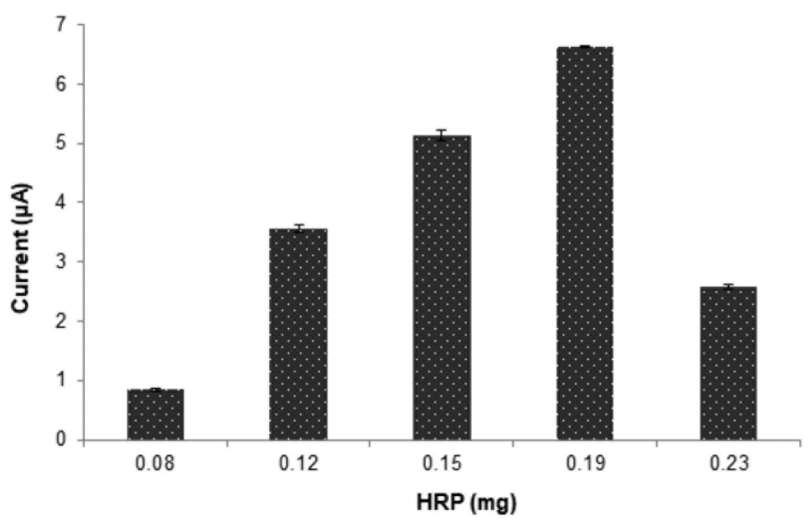

(c)

FIGURE 3. Effect of AuNPs loading (a), MSP-NAS loading (b) and HRP enzymes loading

(c) on the hydrogen peroxide-HRP biosensor 
K-phosphate buffer was employed for further studies to optimize the enzymatic reaction.

The $\mathrm{pH}$ of the buffer solution is influential to the enzymatic reaction in the manner that highly acidic or basic environment may give negative effect to the electrode (Ulianas et al. 2011). Moreover, enzymes are denatured in extreme $\mathrm{pH}$ change. The experiment displayed the response of $\mathrm{H}_{2} \mathrm{O}_{2}$ - $\mathrm{HRP}$ biosensor increased by the reduction of the acidity (from pH5.0 to pH6.0) and declined until $\mathrm{pH} 9.0$. This demonstrate that HRP enzymes react with $\mathrm{H}_{2} \mathrm{O}_{2}$ favorably at $\mathrm{pH} 6.0$. The $\mathrm{pH}$ profile of the hydrogen peroxide- HRP biosensor is shown in Figure 4(b).

In typical enzymatic reactions, the effect of buffer concentration is essential to be evaluated since a suitable concentration of buffer concentration is needed to maintain the activity and stability of the enzymes. The optimum buffer concentration of $\mathrm{H}_{2} \mathrm{O}_{2}$-HRP biosensor was investigated using K-phosphate buffer concentrations from 0.5 until $50 \mathrm{mM}$ as presented in Figure 4(c). K-phosphate buffer with the concentration of $5.0 \mathrm{mM}$ gives the highest current response and selected for further optimization. Table 1 refers to the optimization of experimental parameters.

\section{PERFORMANCE OF HYDROGEN PEROXIDE BIOSENSOR}

The DPV response of the $5 \mathrm{mM} \mathrm{K}$-phosphate buffer containing different molar concentration of hydrogen peroxide was measured with DNA biosensor to construct a
TABLE 1 . The optimization of experimental parameters

\begin{tabular}{lc}
\hline Parameter & Optimized selection \\
\hline Effect of AuNPs loading & $0.05 \mathrm{mg}$ \\
Effect of MSP-NAS loading & $0.04 \mathrm{mg}$ \\
Effect of enzymes loading & $0.19 \mathrm{mg}$ \\
Types of buffer & K-phosphate \\
pH of buffer & pH6 \\
Buffer concentration & $5.00 \mathrm{mM}$ \\
\hline
\end{tabular}

linear calibration curve. The biosensor response increased with increasing concentrations of hydrogen peroxide from $1 \times 10^{-2}-1 \times 10^{-12} \mathrm{M}$ as shown in Figure 5(a). The hydrogen peroxide-HRP biosensor demonstrated a linear response over hydrogen peroxide concentration range from $1 \times 10^{-2}$ to $1 \times 10^{-10} \mathrm{M}\left(\mathrm{R}^{2}=0.99\right)$ with a limit of detection estimated to be less than $1 \times 10^{-10} \mathrm{M}$ (Figure 5(b)). The limit of detection of the hydrogen peroxide biosensor calculated based on three times the standard deviation of the biosensor response in the linear range divided by the linear calibration slope (Nik Mansor et al. 2018).

\section{REPRODUCIBILITY, REPEATIBILITY AND SHELF LIFE OF $\mathrm{H}_{2} \mathrm{O}_{2}$-HRP BIOSENSOR}

The reproducibility of $\mathrm{H}_{2} \mathrm{O}_{2}$-HRP biosensor was satisfactory with most values around 3.45 to $4.21 \%$. Moreover, the

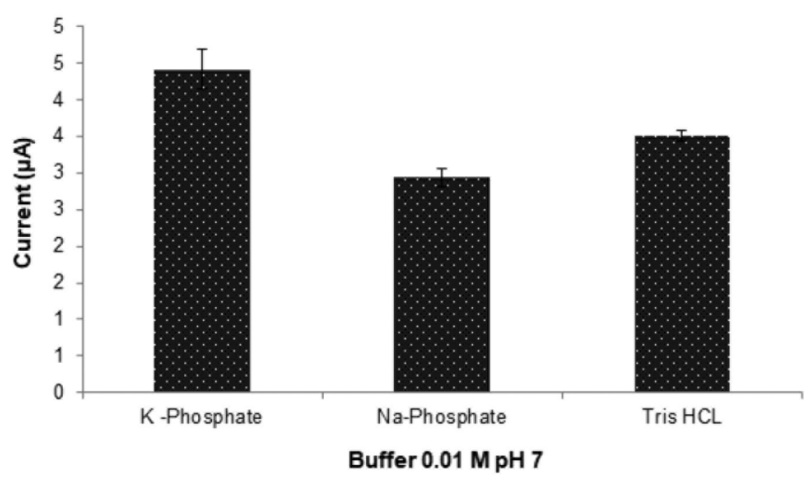

(a)

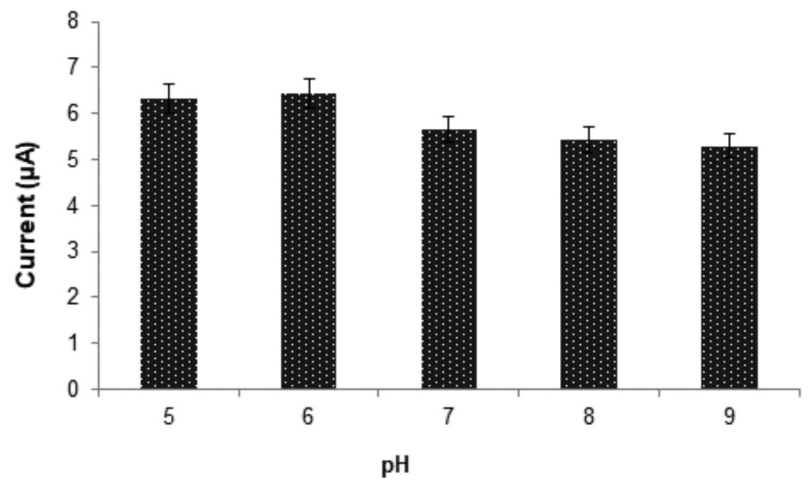

(b)

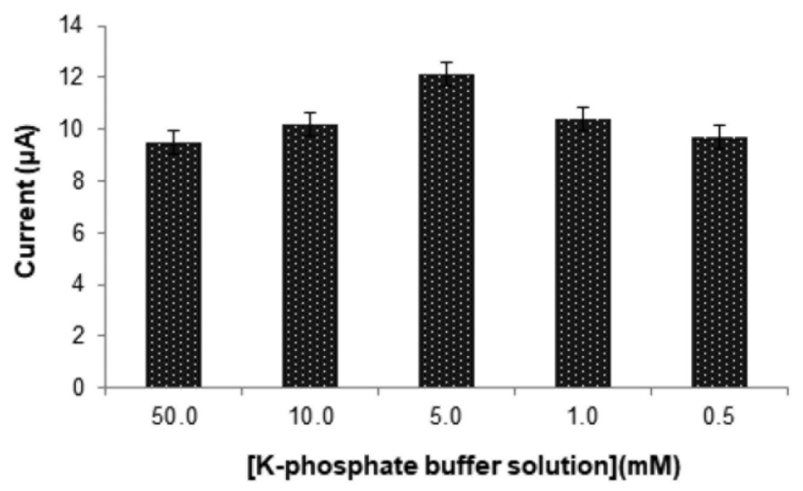

(c)

FIGURE 4. Different types of buffer (a), $\mathrm{pH}$ (b) and buffer concentration (c) profiles of the $\mathrm{H}_{2} \mathrm{O}_{2}$-HRP biosensor 


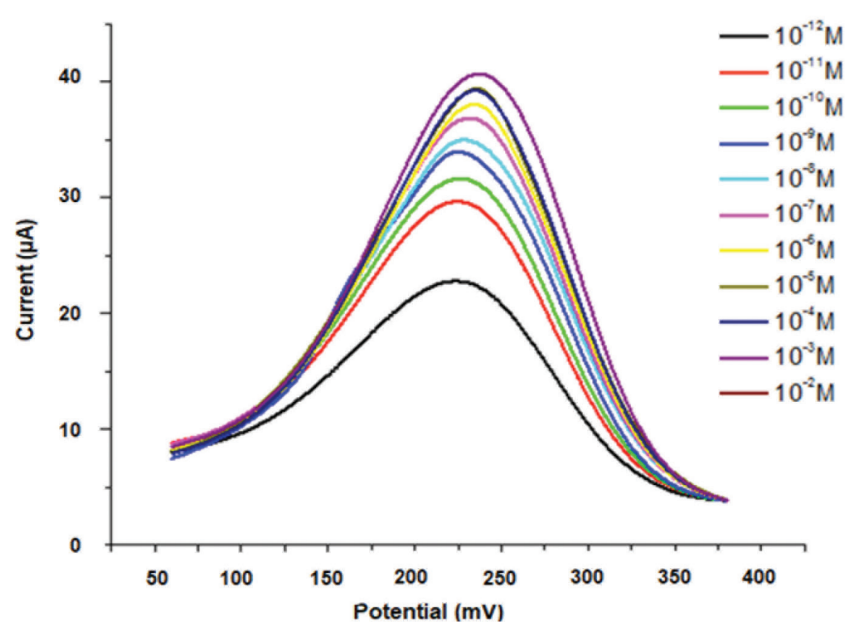

(a)

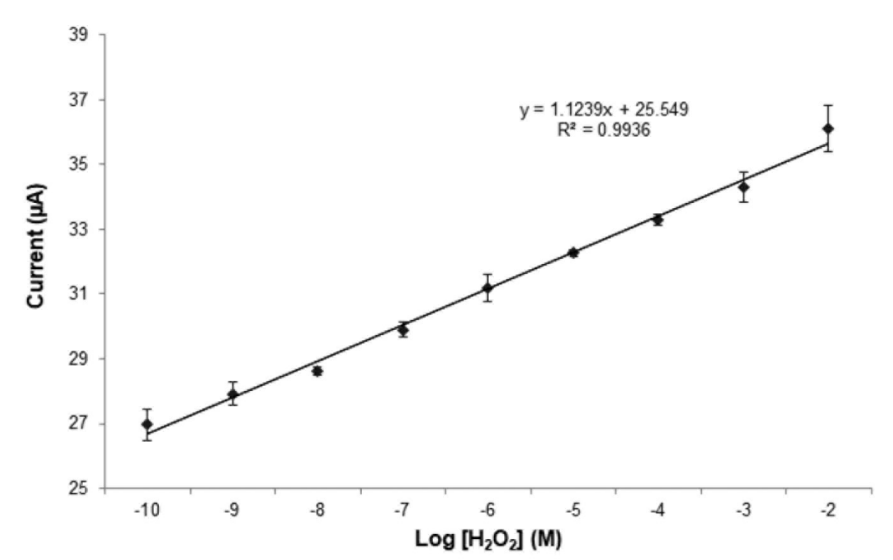

(b)

FIGURE 5. (a) The DPV current response of various concentrations of hydrogen peroxide from $1 \times 10^{-2}$ $\mathrm{M}$ to $1 \times 10^{-12} \mathrm{M}$; (b) The linear response range of the hydrogen peroxide biosensor

repeatability analysis of $\mathrm{H}_{2} \mathrm{O}_{2}$-HRP biosensor demonstrated that the biosensor's response was repeatable over six cycles with repeatability relative standard deviations $4.15 \%$ $(n=6)$. Lastly, the shelf life of $\mathrm{H}_{2} \mathrm{O}_{2}$-HRP biosensor is shown in Figure 6. The $\mathrm{H}_{2} \mathrm{O}_{2}$-HRP biosensor was stored in $\mathrm{K}$-phosphate buffer at $4^{\circ} \mathrm{C}$ before tested. The biosensor response was found stable up to 30 days of storage period with response $92.10 \%$ to $97.36 \%$ when compared to its response on the first day. However, the biosensor response decreased to $17.11 \%$ of the initial value after 80 days of storage period.

The linear range and LOD (limit of detection) properties of AuNPs/MSP-NAS-SPE together with other hydrogen peroxide biosensor platforms are summarized

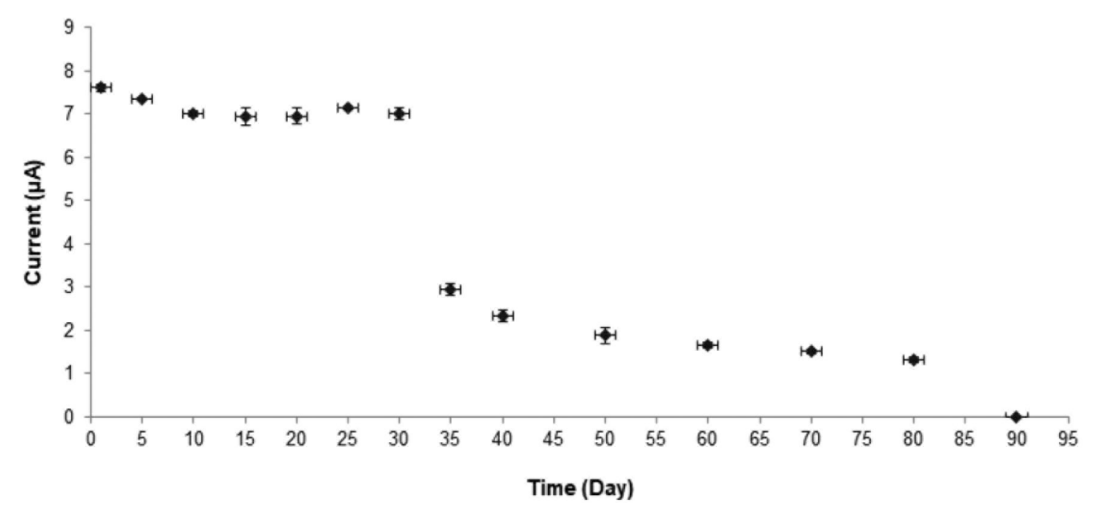

FIGURE 6. Shelf life plot for hydrogen peroxide-HRP biosensor 
TABLE 2. Analytical performance comparisons between the present nanogold AUNPs and other electrochemical biosensors for hydrogen peroxide detection

\begin{tabular}{lccl}
\hline \multicolumn{1}{c}{ HRP supporter } & Linear range (M) & LOD (M) & Reference \\
\hline $\begin{array}{l}\text { AuNPs/MSP-NAS-SPE } \\
\text { Methylene blue N incorporated in a } \\
\text { montmorillonite colloidal particles }\end{array}$ & $5.0 \times 10^{-10}-1.0 \times 10^{-6}-2.2 \times 10^{-6}$ & $6.0 \times 10^{-7}$ & Lei et al. (1996) \\
$\begin{array}{l}\text { Nanocomposites film of carbon nanotubes } \\
\text { (CNTs)-SBA-15 modified gold electrode }\end{array}$ & $1.0 \times 10^{-6}-7.0 \times 10^{-3}$ & $0.5 \times 10^{-6}$ & Fang et al. (2011) \\
$\begin{array}{l}\text { Anthraquinone for redox mediation of HRP on } \\
\text { a glassy carbon electrode substrate }\end{array}$ & & $40 \times 10^{-9}$ & Duo et al. (2009) \\
$\begin{array}{l}\text { Wiring HRP on gold nanoparticles-based } \\
\text { nanostructured polymeric network }\end{array}$ & $5.0 \times 10^{-6}-1.1 \times 10^{-3}$ & & Villalonga et al. (2011) \\
$\begin{array}{l}\text { Immobilized HRP/NanoCeO } / \text { ITO } \\
\text { deposition of gold nanoparticles (AuNPs) onto } \\
\text { a three dimensional (3D) porous carbonized } \\
\text { chicken eggshell membrane (CESM) }\end{array}$ & $0.01 \times 10^{-3}-2.7 \times 10^{-3}$ & $3 \times 10^{-6}$ & Ansari et al. (2009) \\
$\begin{array}{l}\text { Immobilized HRP on a glassy carbon electrode } \\
\text { by poly (glycidyl methacrylate-co-vinyl (2015) } \\
\text { ferrocene) (poly(GMA-co-VFc)) film }\end{array}$ & $2.0 \times 10^{-3}-30.0 \times 10^{-3}$ & $2.6 \times 10^{-6}$ & Senel et al. (2010) \\
$\begin{array}{l}\text { Immobilized anthraquinone 2-carboxylic acid } \\
\text { modified HRP }\end{array}$ & $2.65 \times 10^{-9}$ to $1.08 \times 10^{-7}$ & $1.44 \times 10^{-9}$ & Shourian \& Ghourchian (2010) \\
\hline
\end{tabular}

in Table 2. High linear range and low detection limit displayed by the present nanogold system is a big improvement. This is attributed to the large surface area for enzyme immobilization provided by the microspheres matrix.

\section{CONCLUSION}

A hydrogen peroxide biosensor based on the immobilization of horseradish peroxidase on acrylic microsphere was successfully fabricated. Hydrogen peroxidase enzyme, acrylic microsphere and gold nanoparticles were coated onto SPE. The hydrogen peroxide biosensor showed good performance for the analysis of hydrogen peroxide in various concentrations. The biosensor demonstrated good sensitivity, wide linear response range and low limit of detection.

\section{ACKNOWLEDGEMENTS}

The authors express their gratitude to Centre for Advanced Materials \& Renewable Resources, Faculty of Science and Technology and Centre for Research and Instrument, Universiti Kebangsaan Malaysia for laboratory and instrumental facilities. This work received financial assistance from Universiti Kebangsaan Malaysia (GUP2016-059).

\section{REFERENCES}

Ansari, A.A., Solanki, P.R. \& Malhotra, B.D. 2009. Hydrogen peroxide sensor based on horseradish peroxidase immobilized nanostructures cerium oxide film. Journal of Biotechnology 142: $179-184$
Ariffin, E.Y., Lee, Y.H., Futra, D., Tan, L.L., Karim, N.H.A., Ibrahim, N.N.N. \& Ahmad, A. 2018. An ultrasensitive hollow-silica-based biosensor for pathogenic Escherichia coli DNA detection. Analytical and Bioanalytical Chemistry 410(9): 2363-2375.

Cao, Z., Jiang, X., Xie, Q. \& Yao, S. 2008. A third-generation hydrogen peroxide biosensor based on horseradish peroxidase immobilized in a tetrathiafulvalenetetracyanoquinodimethane/multiwalled carbon nanotubes film. Biosensors and Bioelectronics 24: 222-227.

Chen, S., Yuan, R., Chai, Y., Xu, L., Wang, N., Li, X. \& Zhang, L. 2006. Amperometric hydrogen peroxide biosensor based on the immobilization of horseradish peroxide (HRP) on the layer-by-layer assembly films of gold colloidal nanoparticles and toluidine blue. Electroanalysis 18(5): 471-477.

Ciszewski, A. \& Gorski, Z. 1995. Stripping measurements of hydrogen peroxide based on biocatalytic accumulation at a horseradish peroxidase/ferrocene/carbon paste electrode. Electroanalysis 7(5): 495-497.

Dou, Y., Haswell, S., Greenman, J. \& Wadhawan, J. 2009. Immobilized antraquinone for redox mediation of horseradish peroxidase for hydrogen peroxide sensing. Electrochemistry Communications 11: 1976-1981.

Fang, Z-H., Lu, L-M., Zhang, X-B., Li, H-B., Yang, B., Shen, G-L. \& Yu, R-Q. 2011. A third-generation hydrogen peroxide biosensor based on horseradish peroxidase immobilized in carbon nanotubes/SBA/15 film. Electroanalysis 23(10): 2415-2420.

Garjonyte, R., Yigzaw, Y., Meskys, R., Malinauskas, A. \& Gorton, L. 2001. Prussian Blue- and lactate oxidase- based amperometric biosensor for lactic acid. Sensors and Actuators B 79: 33-38.

Guilbault, G. \& Lubrano, G. 1973. An enzyme electrode for the amperometric determination of glucose. Analytica Chimica Acta 64: 439-455. 
Hirst, N.A., Hazelwood, L.D., Jayne, D.G. \& Millner, P.A. 2013. An amperometric lactate biosensor using $\mathrm{H}_{2} \mathrm{O}_{2}$ reduction via a Prussian Blue impregnated poly(ethyleneimine)surface on screen printed carbon electrodes to detect anastomotic leak and sepsis. Sensors and Actuators B 186: 674-680.

Lei, C., Zhang, Z., Liu, H., Kong, J. \& Deng, J. 1996. Biosensoring of hydrogen peroxidase using new methtlene blue $\mathrm{N}$ incorporated in a montmorillonite-modified horseradish peroxidase immobilization matrix as an electron shuttle. Analytica Chimica Acta 332: 73-81.

Lei, C-X., Hu, S-Q., Gao, N., Shen, G-L. \& Yu, R-Q. 2004. An amperometric hydrogen peroxide biosensor based on immobilizing horseradish peroxidase to a nano-Au monolayer supported by sol-gel derived carbon ceramic electrode. Bioelectrochemistry 65: 33-39.

Lin, X-Q., Chen, J. \& Chen, Z-H. 2000. Amperometric biosensor for hydrogen peroxide based on immobilization of horseradish peroxidase on methylene blue modified graphite electrode. Electroanalysis 12(4): 306-310.

Radi, A-E., Lates, V. \& Marty, J-L. 2008. Mediatorless hydrogen peroxide biosensor based on horseradish peroxidase immobilized on 4-carboxyphenyl film electrografted on gold electrode. Electroanalysis 20(23): 2557-2562.

Ricci, F., Amine,A.,Palleschi, G. \& Moscone, D. 2003. Prussian Blue based screen printed biosensors with improved characteristics of long-term lifetime and $\mathrm{pH}$ stability. Biosensors and Bioelectronics 18: 165-174.

Senel, M., Cevik, E. \& Abasiyanik, M.F. 2010. Amperometric hydrogen peroxide biosensor based on covalent immobilization of horseradish peroxidase on ferrocene containing polymeric mediator. Sensors and Actuators B 145: 444-450.

Shourian, M. \& Ghourchian, H. 2010. Biosensing improvement of horseradish peroxidase towards hydrogen peroxide upon modifying the accessible lysines. Sensors and Actuators $B$ 145: 607-612.

Ulianas, A., Nurlely, Y., Lee, Y.H. \& Tan, L.L. 2018. Synthesis and optimization of acrylic $\mathrm{N}$-acryloxysuccinimide copolymer microspheres. International Journal on Advanced Science 8(3): 780-784.

Ulianas, A., Lee, Y.H., Ahmad, M., Lau, H.Y., Ishak, Z. \& Tan, L.L. 2014. A regenerable screen-printed DNA biosensor based on acrylic microsphere-gold nanoparticle composite for genetically modified soybean determination. Sensors and Actuators B 190: 694-701.

Ulianas, A., Lee, Y.H., Hanifah, S.A. \& Tan, L.L. 2012. An electrochemical DNA microbiosensor based on succinimidemodified acrylic microspheres. Sensors 12(5): 5445-5460.

Ulianas, A., Lee, Y.H. \& Ahmad, M. 2011 . A biosensor for urea from succinimide-modified acrylic microspheres based on reflectance transduction. Sensors 11(9): 8323-8338.

Villalonga, R., Diez, P., Yanez-Sedeno, P. \& Pingarron, J.M. 2011. Wiring horseradish peroxidase on gold nanoparticles-based nanostructured polymeric network for the construction of mediatorless hydrogen peroxide biosensor. Electrochimica Acta 56: 4672-4677.
Wang, J. 2001. Glucose biosensors: 40 years of advances and challenges. Electroanalysis 12: 983-988.

Wang, L. \& Wang, E. 2004. A novel hydrogen peroxide sensor based on horseradish peroxidase immobilized on colloidal $\mathrm{Au}$ modified ITO electrode. Electrochemistry Communications 6: 225-229.

Xu, J-J.,Zhou, D-M. \& Chen, H-Y. 1998. A reagentless hydrogen peroxide biosensor based on the coimmobilization of thionine and horseradish peroxidase by their cross-linking with glutaraldehyde on glassy carbon electrode. Electroanalysis 10(10): 713-716.

Yu, D., Blankert, B., Bodoki, E., Bollo, S., Vir'e, J-C., Sandulescu, R., Nomura, A. \& Kauffmann, J-M. 2006. Amperometric biosensor based on horseradish peroxidaseimmobilised magnetic microparticles. Sensors and Actuators $B$ 133: 749-754.

Zhang, Y.L., Jin, S-Z., Zhang, C-X. \& Shen, H-X. 2001. Studies on electrocatalytical kinetic behaviour of horseradish peroxide and assay for hydrogen peroxide at salt bridge supported bilayer lipid membrane. Electroanalysis 13(2): 137-142.

Zhang, D., Zhao, H., Fan, Z., Li, M., Du, P., Liu, C., Li, Y., Li, H. \& Cao, H. 2015. A highly sensitive and selective hydrogen peroxide biosensor based on gold nanoparticles and threedimensional porous carbonized chicken eggshell membrane. PLOS ONE 10(6): e0130156.

Eda Yuhana Ariffin, Nik Nurhanan Nik Mansor, Lee Yook Heng \& Nurul Izzaty Hassan*

Centre for Advanced Materials and Renewable Resources

Faculty of Science and Technology

Universiti Kebangsaan Malaysia

43600 UKM Bangi, Selangor Darul Ehsan

Malaysia

Eka Safitri

Department of Chemistry

Faculty of Mathematics and Natural Sciences

Syiah Kuala University (USK)

Darussalam-Banda Acheh 23111

Indonesia

*Corresponding author; email: drizz@ukm.edu.my

Received: 19 November 2018

Accepted: 8 April 2019 